\section{Professor Sampat K. Tandon - A Profile} IUGS Councillor (2010-2014)

Born in 1945 in Delhi, Sampat Tandon had his early school education in Andhra Pradesh (South India) and high school education in Uttar Pradesh (North India). He started his studies in Geology at the Punjab University, Chandigarh in 1961, obtaining his Bachelor's degree with honours in 1965 and the Master's degree in 1966. After a two year

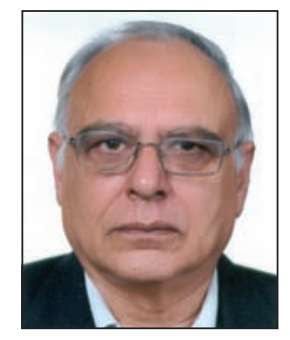

stint as an Associate Lecturer at the Indian Institute of Technology, Delhi engaged in teaching Engineering Geology to Civil Engineering students, he moved to the Univer- sity of Delhi in 1968 to pursue doctoral work. His $\mathrm{PhD}$ thesis was centered on the sedimentary analysis of the Neogene Siwalik succession in a part of the Himalayan Foreland in the Kumaun Himalaya. In 1971, he took up the position of Scientific Officer in the then newly established Wadia Institute of Himalayan Geology. This research institute was started primarily with the intent of stepping up geoscientific investigations in the relatively remote and less explored terrains of the Himalayan orogenic belt. Sampat 
Tandon contributed during this period (19711976) to programmes on the regional tectonic framework of Arunachal Pradesh in the NE Himalaya. In 1976, Sampat Tandon returned to the Geology Department of the University of Delhi as a Reader (Associate Professor) and was appointed as Professor in 1986. During his long career at the University of Delhi, Professor Tandon occupied several positions such as Head, Department of Geology; Dean, Faculty of Science; Dean, Research and International Relations, and Pro-Vice Chancellor for a five year term from 2005-2010. He retired from his position at the University of Delhi in August, 2010.

As a researcher in the field of Geosciences, Prof. Tandon's interests are in Physical Stratigraphy, Sedimentology, Quaternary Geology and Palaeoclimate. His recent work has focused on (a) the responses of late Quaternary fluvial systems to shifts in monsoonal precipitation, and (b) tectonic geomorphology of a part of the Himalayan front. In collaboration with his students and associates, he has explored the differential sensitivity of a desert river (Luni) and a desert margin river (Sabarmati) in response to climate change in the Thar, Northwest India. $\mathrm{He}$ and his collaborators have explored the influence of late Quaternary monsoonal precipitation shifts on large river systems, particularly in the axial and southern part of the Ganga dispersal system. Some of this work was integrated with IGCP 449 (Global Correlation of late Cenozoic fluvial deposits, 2000-2004) of which he was a co-leader. During the late eighties and the nineties, Sampat Tandon was involved with a project on the Late Cretaceous Palaeogeography of Central India. These studies highlighted the influence of Deccan volcanism on contemporary sedimentary environments. These studies were integrated into IGCP 350 - (Cretaceous Environmental change in East and South Asia, 1993-1998). He was also the Regional Co-ordinator, India for IGCP 350.

During the course of his international collaborations, Sampat Tandon has worked on the use of calcretes for furthering understanding of late Palaeozoic successions in Arran, Scotland (with Peter Friend in the Department of Earth Sciences, University of Cambridge, Cambridge, UK - 1984- 85) and in the Sydney basin Atlantic Canada (with Martin Gibling of the Department of Earth Sciences, Dalhousie University, Halifax,
Canada - 1993-94). His other collaborative studies have been with the Geological Institute, Budapest on the Hungarian plain; the University of Karlsruhe, Germany on assessing the stable isotopic composition of Ganga plain calcretes for palaeoclimatic reconstruction; and the Institute of Hazard and Risk Research, University of Durham, UK on the nature of sediment fluxes from the Himalaya and their role in flood hazard.

In the initial stages of his career, Sampat Tandon was involved with the application of dating methods (magnetic polarity, luminescence dating, zircon fission track dating) to Neogene and Quaternary continental sequences in the Himalayas and in Western India.

Sampat Tandon has served on several important committees and boards in India. This includes the SERC (Science and Engineering Research Council) of the Department of Science and Technology (DST), Government of India. He was the Chairperson of the Projects Advisory Committee of Earth Sciences, DST between 1997-2000 and 2003-2006. He has also been the Chairperson of the Research Advisory Committee of the Wadia Institute of Himalayan Geology, Dehradun and steered the preparation of a Vision document for the Institute. Sampat has been keenly involved, for more than two decades, in manpower development in Earth Sciences in India and in nurturing young geoscientists. He is the current Chair of the DST Young Scientist Fast-track scheme for Earth Sciences. He has also been associated in an advisory capacity with the Birbal Sahni Institute of Palaeobotany, Lucknow; the Centre for Earth Science Studies, Thiruvananthapuram; and the Geological Studies unit of Indian Statistical Institute, Kolkata. He was also a Member of the Expert Committee set up by the Govern-ment for the re-structuring and re-organi-zation of the Geological Survey of India in 2002-2003; he also served the Indian National Committee for IUGS between 1997 2000 .

Sampat Tandon was awarded the Indian National Young Scientist Medal in 1974, the Krishnan Gold Medal of the Indian Geophysical Union in 1985, and the CSIR Shanti Swaroop Bhatnagar Prize in Earth Science in 1988. He has been the Secretary, Geological Society of India for three terms (1986-89, 1989-92, and 1998-2001) and is currently one of the Vice-Presidents of the
Society. He is also the President of the Indian Association of Sedimentologists (IAS). Sampat Tandon has been elected to the Fellowship of the three Science Academies in India - Indian National Science Academy, the Indian Academy of Sciences and the National Academy of Science. In 2001, he was elected Fellow of Third World Academy of Sciences, and in 2009 he was presented the Chevalier Dans l'Ordre des Palmes by France.

Sampat Tandon has also delivered several prestigious lectures that include (a) $50^{\text {th }} \mathrm{Sir}$ Albert Seward Memorial Lecture, BSIP, Lucknow, 2004, (b) VII Karunakaran Endowment Memorial Lecture Award, Centre for Earth Science Studies, Thiruvananthapuram, 2006, (c) West Memorial Lecture, Wadia Institute of Himalayan Geology, 2009, (d) $15^{\text {th }}$ Keshav Dev Malaviya Lecture, ONGC 2010 and (e) L.N. Kailasam Endowment Lecture Award, Indian Geophysical Union, 2010.

Sampat Tandon has co-edited 10 books/ theme based special issues of journals, written a dozen book reviews, and published more than 100 papers on subjects ranging from the tectonic geomorphology of the Himalayan front, continental carbonates, sedimentary evolution of the Himalayan foreland, influence of Deccan volcanism on contemporary sedimentary environments, responses of fluvial systems to monsoonal shifts and the use of calcretes and calcareous palaeosols in sequence stratigraphy.

An enthusiast of inter- and multidisciplinary approaches to problem-solving, he advocates the adoption of an Earth Systems philosophy to understand Earth surface processes of a human-transformed Earth.

Following retirement from his official position in the University, he is involved in (a) INSPIRE camps conducted for high school students to encourage them to take interest in Earth science, (b) the development of River Science in India, and (c) researching on connectivity in large river dispersal systems with special reference to the Kosi avulsion event of August, 2008. He is also engaged with the Mathematical Science Foundation, New Delhi as a Distinguished Professor. This Foundation (MSF) aims to spread the application of Mathematic thinking to all realms of knowledge.

Sampat Tandon lives in Gurgaon, an urban sprawl in the National Capital Territory of Delhi, India. 